\title{
从触觉感知到触觉智能——漫谈2021年度诺贝尔 生理学或医学奖
}

陈思 ${ }^{1}$, 张建朋 $^{2}$, 彭争春 ${ }^{2 *}, 丁$ 建宁 ${ }^{1}$

1. 江苏大学流体机械工程技术研究中心, 镇江 212013;

2. 深圳大学物理与光电工程学院, 柔弹性电子研究中心, 深圳 518060

*联系人, E-mail: zcpeng@szu.edu.cn

超灵敏的感官是许多动物在大自然中能够生存的利器, 例如鹰的视觉、蝙蝠的听觉、熊的嗅觉等. 人类不但拥有视 觉、听觉、嗅觉感知能力, 还拥有高度发达的触觉. 早有研 究表明, 人类皮肤能够感知振幅小至 $10 \mathrm{~nm}$ 的振动刺激 ${ }^{[1]}$. 之 后又有科学家发现，人类触觉感知的极限还不止于此. Carpenter等人 ${ }^{[2]}$ 在近原子级光滑硅片表面上分别制备了单层的 氟化烷基硅烷 (FOTS, 分子直径为 $0.206 \mathrm{~nm}$ )和单层硅羟基 $(\mathrm{SiOH}$, 分子直径为 $0.203 \mathrm{~nm})$, 实验结果显示人类皮肤能够分 辨出这两种单分子层的差别. 2021年诺贝尔生理学或医学奖 颁给了美国加州大学旧金山分校的戴维·朱利叶斯(David Julius)和Scripps研究所的阿德姆·帕塔普蒂安(Ardem Patapoutian), 以奖励他们分别独立发现了温度和触觉的受体. 这一 发现揭示了人体皮肤感知温度、压力及疼痛的分子机制，回 答了有关人类触觉感知的一个根本问题: 外部的温度和机械 刺激是如何转化为内部的神经冲动.

\section{1 触觉感知}

在我国经史子集中, 对触觉的描述不一而足, 比如: 《易 传》有“寒暑相推而岁成也”, 在冷热感知之上建立起朴素的 时间观; 《荀子》有“温润而泽, 仁也”, 以冷暖知觉对仁定 义; 《孟子》有 “文王视民如伤”, 以痛为爱 ${ }^{[3]}$. 在西方哲学的 起源时期, 亚里士多德更为系统地阐述了触觉感知, 他把触 觉置于经验感官的中心, 认为触觉很可能是各种感觉能力的 综合, 是最基本、最重要的感觉. 19世纪, 生理学的发展和观 测手段的进步, 促成了帕西尼小体(Pacinian Corpuscle) $)^{[4]}$ 和默 克尔细胞 (Merkel's Cell) ${ }^{[5]}$ 等触觉感受器的发现, 揭开了触觉 生理学研究的序幕. 奥地利物理学家、哲学家恩斯特·马赫 (Ernst Mach) ${ }^{[6]}$ 的《感觉的分析》一书也在这一时期完成. 他 认为各种感觉因素的集合才形成物体和自我, 而触觉是其中 的一个重要因素, 并对触觉空间性和视觉空间性的一致性关 系作了一定的分析. 但之后长达一个世纪的时间，相较于视 觉、听觉等其他感官, 触觉的研究似乎陷人了沉寂, 主要原 因在于其感知机制、复现和数字化进程困难重重.

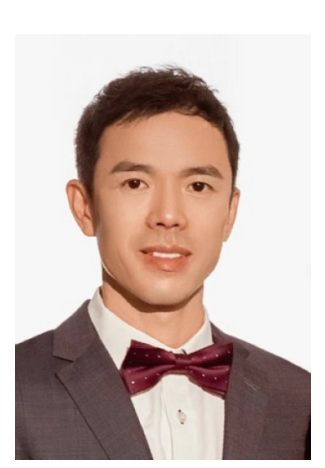

彭争春深圳大学特聘教授, 国家 重大人才工程计划入选者, 深圳市高 层次人才创新团队项目带头人. 主要 从事微纳传感器、电子皮肤与机器 触觉、皮肤集成电子及触觉 AR(augmented reality)、医疗健康、脑机接 口等研究.

在触觉受体发现之前，触觉发生机制尚未清晰，触觉量 化主要以“表征+计算”的范式进行，即把整个触觉感知系统 作为黑匣子, 仅讨论输人输出相关性, 显然不利于触觉的精 确定量. 而温度受体 ${ }^{[7]}$ 和触觉受体 ${ }^{[8]}$ 的发现, 有望实现建立外 部刺激与相应兴奋细胞产生的神经冲动之间的精确定量关 系. 自2010年被发现以来，Piezo蛋白被证明广泛分布在人体 不同组织和器官中, 如图 1 所示 ${ }^{[9]}$. 在特定的机械刺激下, 以 Piezo蛋白为亚单位构成的离子通道会作出响应并打开, 允许 带正电荷的离子流人细胞 ${ }^{[8]}$. Piezo蛋白家族中两种离子通道 Piezo1和Piezo2的激活方式不同, Piezo1可以由正压或负压激 活, 而Piezo2仅能被正压激活 ${ }^{[10]}$. 它们在体内的分布也不相 同, Piezo1多存在于流体动态压力环境中的非感觉组织, 赋予 非兴奋性细胞机械敏感性，如参与红细胞体积调节及感知剪 应力(图1(d))、感知流经肾脏的液体(图1(e))等. Piezo2主要在 感觉神经细胞中被表达, 在轻触和本体感觉(图1(a))、神经元 及环境间的机械特性感知(图1(c))等方面起作用. 而对一些特 定部位如关节软骨细胞的应力感知(图1(b)), Piezo1和Piezo2 均有参与 ${ }^{[9]}$. 清华大学肖百龙课题组 ${ }^{[1,12]}$ 利用电生理膜片钳 和冷冻电子显微镜等技术手段, 完成了Piezo1和Piezo2通道 的冷冻电子显微镜结构解析. 他们的研究有力推动了对哺乳 动物机械门控Piezo通道的结构和机械门控机制的理解. 近年 来, 研究人员已经开发出多种体外刺激Piezo蛋白离子通道的 


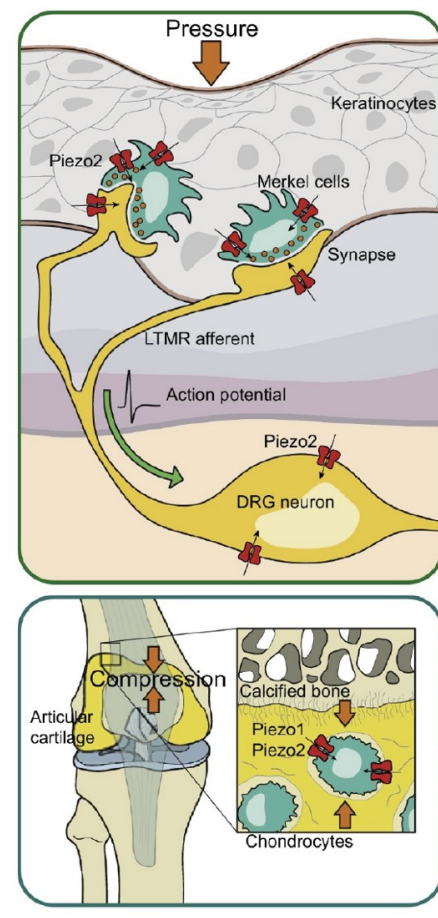

(a)

(c)

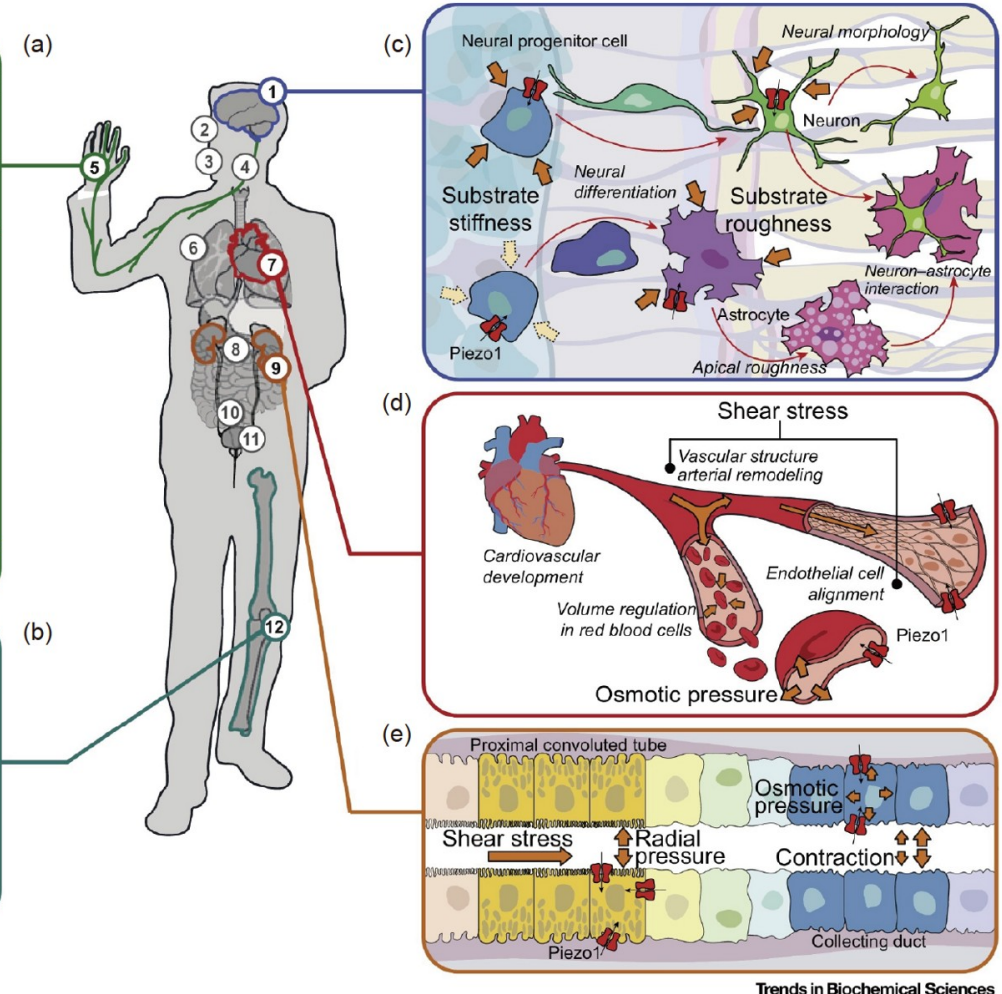

(d)

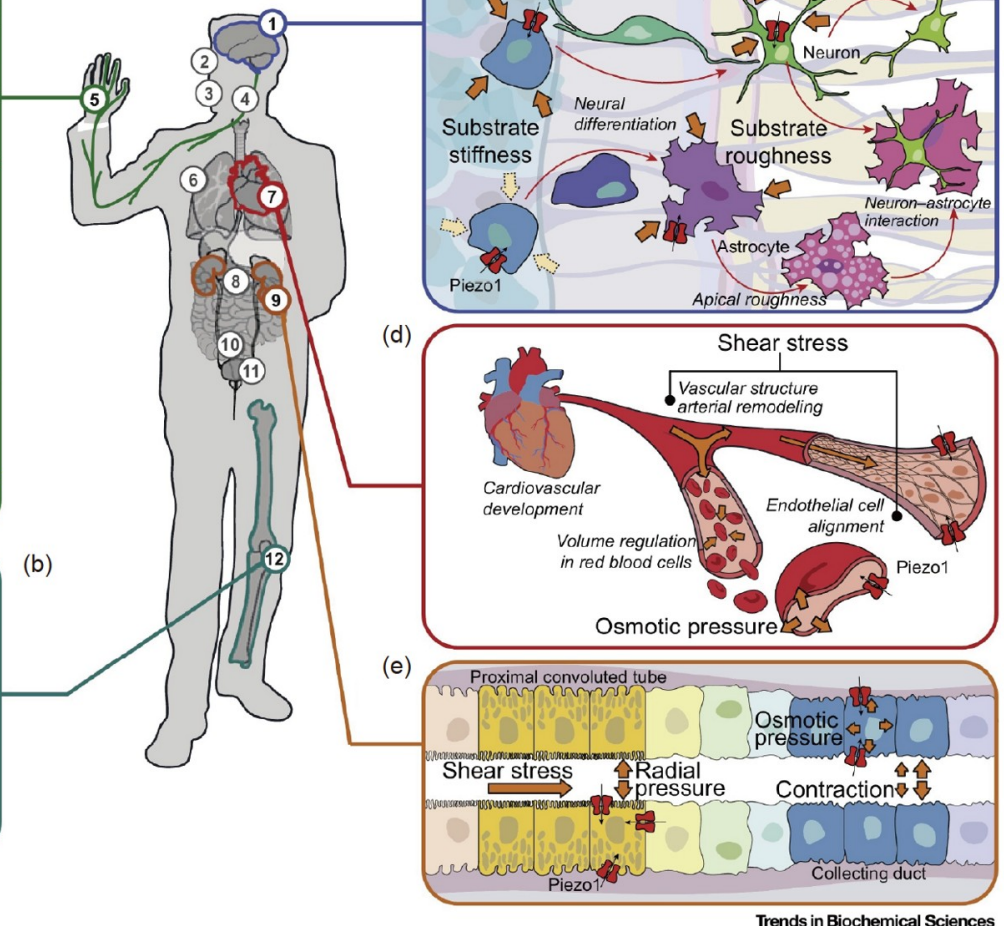

(b)

图 1 (网络版彩色)Piezo蛋白的表达和生理作用 ${ }^{[9]}$. (a) Piezo2在Merkel细胞和背根节传人神经细胞中的表达. (b) Piezo1和Piezo2在关节软骨细 胞中的表达. (c) Piezol在促进传感神经前体细胞发育中的作用. (d) Piezo1在调节红细胞体积、感应切应力等方面的作用. (e) Piezo1在感知肾脏 中液体流动中所起的作用

Figure 1 (Color online) Expression and physiological roles of Piezos ${ }^{[9]}$. (a) Piezo2 expressed in Merkel cells and dorsal root ganglion cell afferents. (b) The expression of both Piezo1 and Piezo2 in chondrocytes of articular cartilage. (c) The role of Piezo1 in sensing mechanical properties of the environment of neural progenitor cells. (d) The roles of Piezol in regulating volume of red blood cells and sensing shear stress to regulate vascular branching. (e) The role of Piezo1 in sensing fluid flow throughout the nephron of the kidney

技术, 如基于膜片钳电生理学的“拉伸”和“翟”, 基于原子力显 微镜技术的压痕及剪切力测试, 基于化学激动剂或磁性纳米 颗粒的刺激等 ${ }^{[9]}$. 由于每种技术在易用性、采样通道数量以 及刺激和响应的量化方面都有各自的优势与劣势, 目前还没 能阐明机械力如何与离子通道的激活相耦合的机制.

当然，触觉的形成并不是单个细胞或感受器对外界刺激 的响应就可以完成的. 皮肤的方寸之间, 高度密集地分布了 各种触觉感受器和神经末梢. 这些感受器组成团簇分别包埋 在皮肤内, 分工明确, 共同协作, 完成人体与环境的触觉信息 交互. 其中感受器动作电位的波动方向、幅度、持续时间等 反映了外界刺激的特征. 值得注意的是, 这些外界刺激特征 并不直接作用于触觉感受器, 而是通过其附着环境(如皮 肤、肌肉、体内上皮组织等)的变形、振动、流场变化等诱 发触觉感受器的响应.

\section{2 触觉认知}

在心理学上, “感”与“知”是认知过程的两个不同阶段, 分
别对应着“感觉”和“知觉”. 从基本粒子到宇宙星系, 从病毒到 蓝鲸, 几乎每件事物都存在一个本体(noumenon), 并通过表面 或界面(surface)与外界相隔离区分. 对本体的感知是意识觉 醒的先决条件. “格物致知”表达的是要量度、辨识事物才能 获得认知.

触觉是人认识并理解这个世界的重要手段. 18世纪, 法 国哲学家孔狄亚克(Etienne Bonnot de Condillac)论述了触觉 认知之于人类智能的重要性 ${ }^{[13]}$. 他认为触觉是感官世界的中 心, 其他感官均以触觉为基础复合而成, 触觉从内容方面指 导着其他感官和感觉. 不通过其他感官仅依靠触觉来识别物 体及其属性特征, 我们称之为察知触觉(discriminative touch). 察知触觉可以识别物体的表面特征(表面纹理、颗粒感、黏 着度等)、空间特征(轮廓、形状、体积等)、材料属性(软硬 度、密度、黏度等). 另外, 不同材质的物体, 其接触温度也不 尽相同, 而皮肤中的温度受体(thermo transient receptor potential)可以提供丰富的温度感觉信息 ${ }^{[7]}$, 使得触觉甚至可以识别 物体的材料组成, 如金属、木头等. 1944年, 美国科学家约瑟 
夫·厄兰格(Joseph Erlanger)和赫伯特·加瑟(Herbert Gasser)获 得了诺贝尔生理学或医学奖, 他们发展了阴极射线示波器, 可以记录神经纤维的动作电位. 自此, 触觉的神经生理学机 制研究开始活跃起来. 触觉感知到的特征信息被转化为动作 电位传递到大脑，大脑的高级联合皮层对外界刺激进行精细 分析, 结合过去的经验, 产生触觉认知 ${ }^{[14,15]}$.

伴随着触觉认知的过程，情绪、情感会在一定程度上被 唤醒. 比如, 触摸母亲的肌肤可以让婴儿获得安全感, 一块柔 软丝滑的毯子可以让人安睡, 一次有力的握手可以消除紧张 情绪, 这些是触觉给人带来的积极的情感. 触觉也会产生负 面情绪，比如，羽毛或头发在皮肤上移动会让神经系统引起 警觉，诱发焦虑. 这是因为在人体皮肤上存在一群特殊的触 觉传递纤维一C-Tactile纤维, 其属于C纤维的一种, 1939年 由瑞典神经生理学家Zotterman ${ }^{[16]}$ 在猫的皮肤上首次被发现, 此后又被其他学者证实存在于人脸与有汗毛的前臂上. 与传 递痛觉的普通C纤维不同, C-Tactile纤维对于那些动作缓慢、 每秒移动约 $5 \mathrm{~cm}$ 的触觉刺激特别敏感, 且偏好与体温相似的 温度 (由温度受体介导). 有趣的是, 这些刺激的特征与生活中 的按摩、抚摸、亲吻等社交触碰相当吻合. 依靠这些独特的 C-Tactile纤维，我们能感受到他人抚摸、按摩等带来的愉悦 情感, 因此被称为情感触觉(affective touch). Goldstein等人 ${ }^{[17]}$ 研究了“握手镇痛”的神经机制. 如图2所示, 他们以情侣作为 被试，以是否握手和是否施加疼痛刺激作为实验条件，同步 采集了双方的脑电信号，最终发现在疼痛刺激下，情侣的握 手使疼痛者的脑间连接增强, 从而缓解了疼痛.

\section{3 触觉智能}

20 世纪原创媒介理论家马歇尔·麦克卢汉(Marshall McLuhan)提出 ${ }^{[18]}$ ，“身体是大脑的延伸，一切的技术都是人的
延伸”, 大脑控制肢体使用工具是智能的外延和体现. 可见, 感 而致知而后致智. 1956年, 人工智能的概念在Dartmouth学会上 被首次提出. 此后, 随着人工智能的蓬勃发展, 类人智能与人 类智能的关系和挑战日益凸显. 1997年, 由IBM开发的超级电 脑“深蓝”击败了国际象棋世界冠军，20年后人工智能AlphaGo 在围棋中战胜了世界第一围棋手柯洁. 人工智能的发展让类 人智能在复杂思考决策中超越人类，但是日常场景中却难见 其身影. 著名的莫拉维克悖论(Moravec's Paradox) ${ }^{[19]}$ 对此进行 了阐述: “要让计算机在智力测验或象棋比赛中, 实现如成人一 样的表现，是相对比较容易的; 但是要让电脑具备如1岁小孩 般的感知和行动能力, 却是相当困难的，甚至完全不可能实 现.” 莫拉维克悖论可解读为生命与非生命体、人类智能与类 人智能之间的鸿沟. 人类所独有的高阶智慧能力只需要非常 少的计算能力, 但是无意识技能和直觉却更加复杂.

近年来, 美国波士顿动力公司(Boston Dynamics)出品了 四足机器人BigDog和人形机器人Atlas. BigDog与真狗大小 相当，会根据地面状况调节步态以平衡身体，可以打滚、跳 跃，跌倒了甚至能够翻身站起来，并能够在战场上为士兵运 送弹药、食物和其他物品. Atlas则可以在山林雪地里健步如 飞, 通过立体和激光传感器调整以应对地域的变化, 自行完 成运动控制与平衡. 即便如此，目前的人工智能体并不是一 个有意图的施动者, 不能为其动作和行为提供理由，也不能 对外部世界产生意识体验，即机器不理解外部物理世界的内 涵意义，这就是人工智能面临的“物理落地问题”[20]. 这是目 前人工智能和机器意识研究的最大挑战之一, 而其主要原因 可能在于触觉感知及反馈在人工智能发展中的严重缺位.

触觉的基础是对本体的感知，如对四肢相对位置和身体 空间位置的自我感知, 由本体感受器介导. 本体感受器是专 门的机械感觉神经元，传达肌肉、肌腱、皮肤和关节等所经

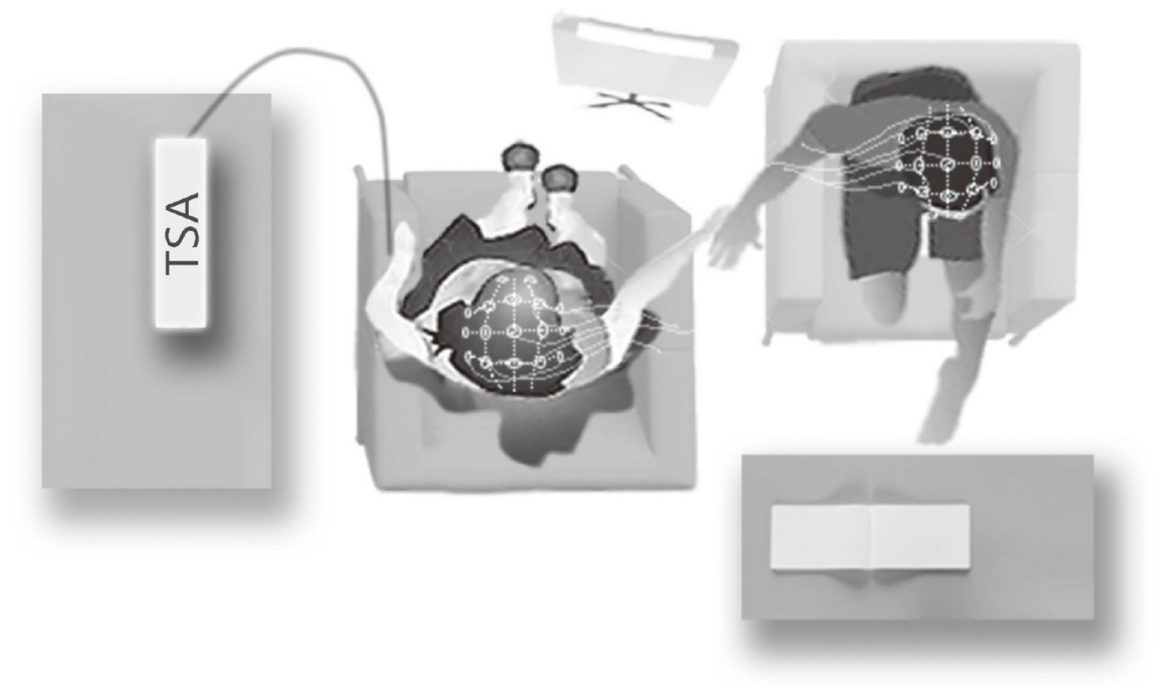

图 2 “握手镇痛”神经机制的实验研究 ${ }^{[17]}$

Figure 2 Experimental study of the neural mechanism of touch-induced analgesia ${ }^{[17]}$ 

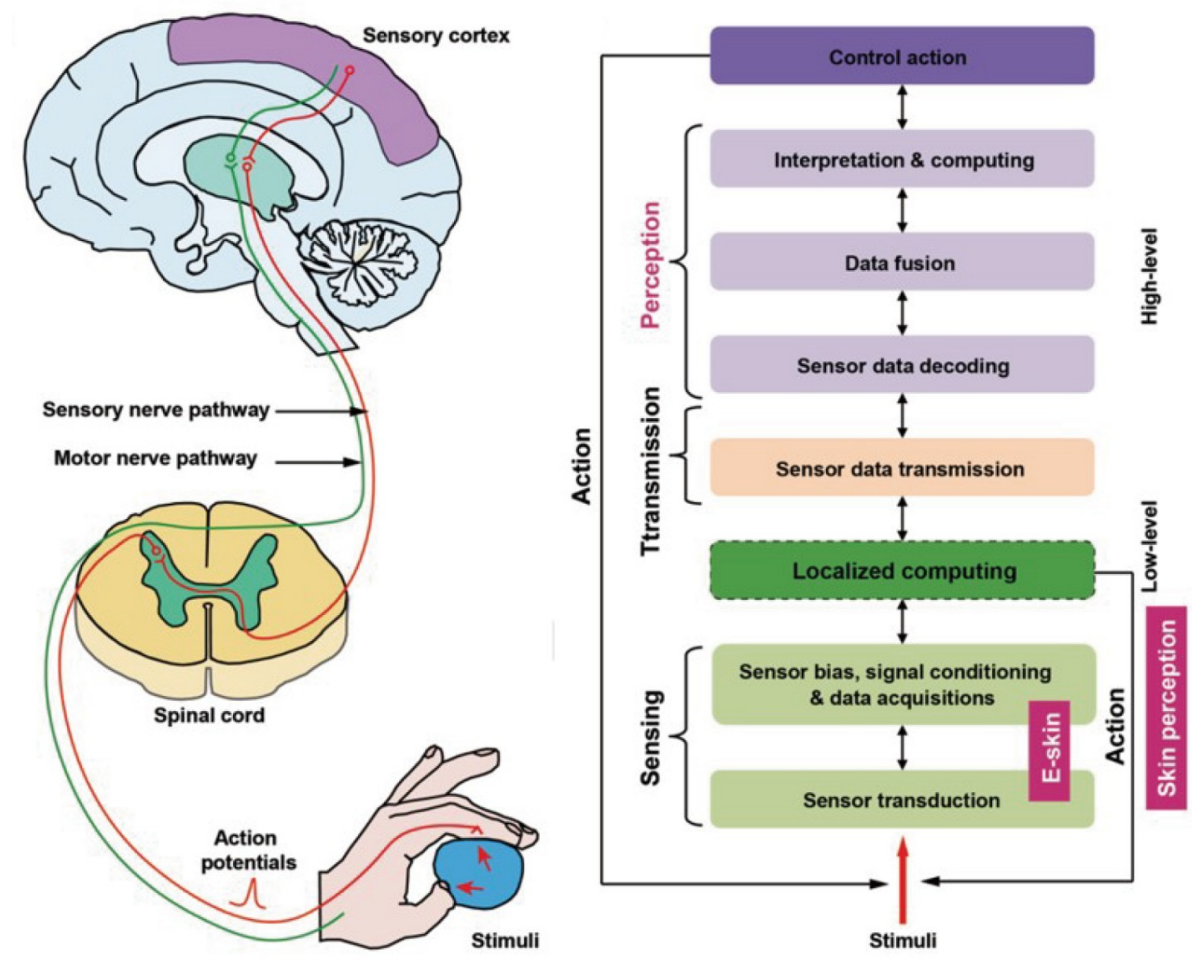

图 3 (网络版彩色)人与人工智能对感知信息的处理过程 ${ }^{[22]}$

Figure 3 (Color online) Processing of sensory information by human vs. by artificial intelligence ${ }^{[22]}$

历的拉伸和张力的信息. 2015年, Patapoutian团队突破性地发 现, 本体感觉(proprioception)由触觉受体Piezo2蛋白介导, 揭 示了本体感觉的分子机制, 从生理学上说明了本体感觉与触 觉同源 ${ }^{[21]}$. 该发现为研究类人智能的触觉系统提供了仿生理 论和依据，对开发包括智能假肢、远程手术机器人在内的需 要临场触觉感知与反馈的智能系统带来很大启发. 同时, 我 们有理由假设, 研究仿生触觉感受器, 建立完整的触觉闭环
回路，对多模态触觉信息进行融合与编码，可对类人智能本 体进行感知和驱动, 让类人智能拥有意识和情感(图 3$)^{[22]}$. 届 时, 研究人员将有望打破莫拉维克悖论, 解决人工智能的“物 理落地问题”.2021年诺贝尔生理学或医学奖授予触觉感知 研究领域, 将大力推动触觉智能的快速发展, 使人工智能早 日突破视觉和听觉智能的局限，向更高层次的类人智能系统 迈进.

致谢感谢国家自然科学基金(51805218)、臱港科技创新联合基金(2021A0505110015)、深圳市创新团队项目 (KQTD20170810105439418)和深圳市重点项目(JCYJ20200109114237902)的资助.

\section{推荐阅读文献}

1 Skedung L, Arvidsson M, Chung J Y, et al. Feeling small: Exploring the tactile perception limits. Sci Rep, 2013, 3: 2617

2 Carpenter C W, Dhong C, Root N B, et al. Human ability to discriminate surface chemistry by touch. Mater Horiz, 2018, 5: 70-77

3 Zhang Z L. Tactile sensation, induction and vibration of the sense in Chinese philosophy (in Chinese). J Jiangsu Adm Instit, 2017, (4): 5-17 [张再 林. 触觉与中国哲学. 江苏行政学院学报, 2017, (4): 5-17]

4 Bentivoglio M, Pacini P. Filippo Pacini: A determined observer. Brain Res Bull, 1995, 38: 161-165

5 Merkel F. Tastzellen und Tastkörperchen bei den Hausthieren und beim Menschen. Archiv Mikroskopische Anatomie, 1875, 11: 636-652

6 Mach E. Sensory Analysis (in Chinese). Beijing: The Commercial Press, 2011 [Mach E. 感觉的分析. 北京: 商务印书馆, 2011]

7 Caterina M J, Schumacher M A, Tominaga M, et al. The capsaicin receptor: A heat-activated ion channel in the pain pathway. Nature, 1997, 389: $816-824$

8 Coste B, Mathur J, Schmidt M, et al. Piezo1 and Piezo2 are essential components of distinct mechanically activated cation channels. Science, 2010, 
330: $55-60$

9 Wu J, Lewis A H, Grandl J. Touch, tension, and transduction—-The function and regulation of piezo ion channels. Trends Biochem Sci, 2017, 42: $57-71$

10 Douguet D, Honoré E. Mammalian mechanoelectrical transduction: Structure and function of force-gated ion channels. Cell, 2019, 179: 340-354

11 Zhao Q, Zhou H, Chi S, et al. Structure and mechanogating mechanism of the Piezol channel. Nature, 2018, 554: 487-492

12 Wang L, Zhou H, Zhang M, et al. Structure and mechanogating of the mammalian tactile channel Piezo2. Nature, 2019, 573: 225-229

13 Condillac E B D. Three Chapters of Condillac's Philosophy (in Chinese). Shanghai: Shanghai People's Publishing House, 2018. 470 [Condillac E B D. 孔狄亚克哲学三篇. 上海: 上海人民出版社, 2018. 470]

14 de Lafuente V, Romo R. Neuronal correlates of subjective sensory experience. Nat Neurosci, 2005, 8: 1698-1703

15 Romo R, Salinas E. Sensing and deciding in the somatosensory system. Curr Opin Neurobiol, 1999, 9: 487-493

16 Zotterman Y. Touch, pain and tickling: An electro-physiological investigation on cutaneous sensory nerves. J Physiol, 1939, 95: 1-28

17 Goldstein P, Weissman-Fogel I, Dumas G, et al. Brain-to-brain coupling during handholding is associated with pain reduction. Proc Natl Acad Sci USA, 2018, 115: E2528-E2537

18 McLuhan M. Understanding media: The extensions of man. Am Quart, 1994, 16: 388

19 Moravec H. Mind Children: The Future of Robot and Human Intelligence. Cambridge: Harvard University Press, 1988

20 Taddeo M, Floridi L. Solving the symbol grounding problem: A critical review of fifteen years of research. J Exp Theor Artif Intell, 2005, 17: 419445

21 Woo S H, Lukacs V, de Nooij J C, et al. Piezo2 is the principal mechanotransduction channel for proprioception. Nat Neurosci, 2015, 18: 17561762

22 Wang M, Luo Y, Wang T, et al. Artificial skin perception. Adv Mater, 2021, 33: 2003014 
Summary for “从触觉感知到触觉智能——漫谈2021年度诺贝尔生理学与医学奖”

\title{
From sense of touch to tactile intelligence: Thoughts from the 2021 Nobel Prize in Physiology or Medicine
}

\author{
Si Chen ${ }^{1}$, Jianpeng Zhang ${ }^{2}$, Zhengchun Peng ${ }^{2 *} \&$ Jianning Ding ${ }^{1}$ \\ ${ }^{1}$ Fluid Machinery Center, Jiangsu University, Zhenjiang 212013, China; \\ ${ }^{2}$ Center for Stretchable Electronics and Nano Sensors, College of Physics and Optoelectronic Engineering, Shenzhen University, Shenzhen 518060, \\ China \\ * Corresponding author, E-mail: zcpeng@szu.edu.cn
}

Human beings have highly developed sense of touch. Through touching we can perceive heat, pain, mechanical stimuli, recognize features of an object such as texture and hardness, and even understand emotion of a person. Hence, human touch is one of the most important ways to sense and adapt to the world around us. However, we had little understanding of how cutaneous perception was formed in our nervous system, until the groundbreaking discoveries were made by this year's Nobel Prize laureates in Physiology or Medicine, David Julius from University of California, San Francisco, and Ardem Patapoutian from Scripps Research. They found that heat and mechanical stimuli can initiate specific nerve impulses for temperature, pain, and touch sensations.

The quest to understand temperature sensation and pain spans millennia. In the early 20th century, the Greek physician Galen proposed that sensations were transmitted along pathways that connect the organs to the brain. It was not until 1997 that the true underlying molecular mechanism was revealed by Julius in a breakthrough work. Julius and his team found that a receptor on the cell's membrane arranges itself from one side to the other, so that it creates a passage called a transient receptor potential (TRP) channel. This ion channel opens or closes in response to heat. Inspired by Julius's work, Patapoutian in the early 21st century explored a mechanosensitive ion channel, called the Piezo channel, and identified that it is essential for the sense of touch. Patapoutian and his team also found that the Piezo channel is responsible for the sensing of position and motion of our body, which explains why we can balance on a steep stair.

Not only did these discoveries elucidate the physiological understanding of human somatosensory, they also enlightened the researchers who work on reproducing such human functions in robotics and prosthetics. The molecular mechanisms of thermo-sensation and mechano-sensation provided a new paradigm for designing artificial cutaneous perception and constructing electronic skin for robots. Once fully armed by tactile perception and haptic feedback, smart robots and artificial intelligence may start to have consciousness and feel emotions like we humans do. With the awarding of the 2021 Nobel Prize in Physiology or Medicine to research in how humans perceive touch and pain, the research in tactile intelligence now has a clearer roadmap and gains a greater momentum. We foresee many exciting breakthroughs in this field in the near future.

cutaneous perception, transient receptor potential ion channel, Piezo ion channel, electronic skin, tactile intelligence

doi: 10.1360/TB-2021-1145 